\title{
AED DUB MAC COLMÁIN, BISHOP-ABBOT OF KILDARE.
}

In the Annals of Ulster the death of this prelate is entered under the year 638 (recte 639), as follows: Quies Cridan $i$ Naendruim 7 Aedha Duib abbad Cille Daro episcoporum. ${ }^{1}$ ) To this notice the Chronicon Scottorum adds: i. ri Laigen, and Tigernach (Rev. Celt. 17, p. 185): ri Laigen ar tús, which has been copied by the Four Masters (7 ba ri Laigen ar tos esidhe). Hennessy (AU p.104, note 4) further states that Aed Dub resigned his kingship in the year 591, and that his name occurs in the form Aed Cerr in the list of the kings of Leinster in LL $39 \mathrm{~b}$. There, in line 13, coming after Colmán Mór mac Corpri we find the entry Aed Cerr mac Colmāin nō Senaig .xıı. i. e. 'Aed Cerr son of Senach reigned twelve years'; for no Senaig, which is repeated in the margin, is meant to cancel Colmain. The letter .e., which is added in the margin, denotes that he died a natural death (éc). The Four Masters enter the obit of this king - on what authority, I do not know, - under 591, calling him, however, Aodh Cerr mac Colmáin mic Coirpre. Thus it seems that Hennessy got the date of the supposed resignation from that of the obit as given by the Four Masters. Neither he nor the Four Masters took any notice of the correction $n \bar{o}$ Senaig in LL. As to this Senach, I think it highly probable that he is identical with Senchán mac Colmáin Móir, whose death Tigernach mentions A. D. 592 (iugulacio Senchaiin maic Colmáin Móir).

It is clear then that Aed Dub abbot of Kildare and Aed Cerr king of Leinster were different persons. The pedigree of

1) This is the reading of the Rawlinson MS. 
the former is given as follows in Rawlinson B 502, p. $124 \mathrm{~b} 36$ : Aed Dub, son of Colmán,1) son of Cairpre, son of Cormac, son of Ailill mac Dúnlainge, of whose race are the kings of Leinster (dia chlaind atāt ind rīg Lagen).

In LL 316 a 26, and again in 387 b 54, we have some further notice of Aed Dub. He is there called Aed Dub mac Colmāin, rígepscop Cille Dara 7 Lagen uli é 7 mac óig[e] é 7 dune amra $i$ n-ecnu. And again: Aodh Dubh mac Colmāin sui eccnai 7 rāghespoc Laigen 7 ab Cille Dara 7 mac ōighi 7 duine amhra $i$ tūaith $7 i$ ceinel. Here rigepscop does not mean that he was or had been a king, but that he belonged by descent to the royal line of Leinster.

This is further borne out by an interesting poem which has not hitherto been edited or translated. It is quoted immediately after the above entries in LL 316 a $28\left(\mathrm{~L}^{1}\right)$ and 388 a $3\left(\mathrm{~L}^{2}\right)$, introduced by Inde quidan cecinit $\left(\mathrm{L}^{1}\right)$ and inde poeta dixit $\left(\mathrm{L}^{2}\right)$. The second stanza is also found in a glossary in H. 3. 18, ${ }^{2}$ ) in illustration of the word coall .i. muinterus. The poem is as follows :

1 A bráthair, $\mathrm{ma}^{3}$ ) dia seichi ${ }^{4}$ for iris, cia dú ${ }^{5}$ ) duit combág ${ }^{6}$ ) fri $h \overline{\mathbb{E}^{4}} d^{7}$ ) $\operatorname{manip}^{8}$ ) gafann ${ }^{9}$ ) atibis?

2 Indat cuirn ${ }^{10}$ ) búabaill do chuirn? is in ${ }^{11}$ ) cuirm Cúalann ${ }^{12}$ ) [do chuirm ${ }^{13}$ )?

in Currech Lifi do thír? in tú úa cóicat ${ }^{14}$ ) ardrig?

is in ${ }^{15}$ ) Cell Dara do chell? is in ${ }^{15}$ ) la Críst do choëll 16)?

1. Oh brother, if you follow faith, what right have you to compete with $\circledast \mathrm{Ed},{ }^{17}$ ) unless indeed you have drunk henbane ${ }^{18}$ )?

1) The other sons of Colmán are enumerated as follows: Falän dalta Coemgin Glinni Dā Locha (iss è in Falān sin senathair sūl Brain), Rōnāu, Māel Huma, ̈̈̀ld Find.

2) I regret that $I$ have lost the reference to the page or column.

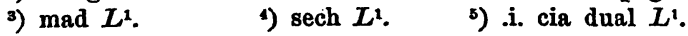

6) combaigh $L^{2}$. 7) ndubh add. $L^{2}$. i. ndub $L^{1}$.

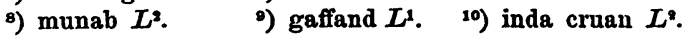

11) 7 in $L^{1}$ indat $L^{2} 7$ inat $H$. 12) Chualann $L^{1}$.

13) coirm $L^{2}$ 14) intua coicat $L^{1}$. inat ua cóica $H$ indat ua .1. $L^{2}$.

15) in $L^{1}$. indat $L^{2}$. inat $H$.

16) coall $7 \mathrm{rl}$. $H$. do thoell- i. do géil[sine .i. do muinte]ras $L^{i}$.i. muinte]ras $L^{1}$. .i. muinterus $L^{2}$. -

17) Cf. ató oc combáig friss im sechim a gníme, Wb. 26 d 17.

18) gafann f. 'henbane'; gen. ola na gafainne, O'Gr. Cat. 178. 
460 K. MEYER, AED DUB MAC COLMÁTN, BISHOP-ABBOT OF KHLDARE.

2. Are your drinking-horns horns of the wild ox? and is your ale ale of Cualu ${ }^{1}$ )? is the Curragh of the Liffey your land? Are you a descendant of fifty high-kings? is Kildare your church? and is your companionship with Christ?

As the $7 r l$. of $\mathrm{H}$ shows the poem is not complete. Perhaps is in Cell Dara begins a new stanza, of which the first line only is preserved. The metre of the first stanza is rannaigecht. In the second, the first line shows the same metre, but the next two lines as they stand are in debide. It may be questioned, however, whether ardrig is the correct reading. If the poem is Old-Irish, iia would still be a disyllable, in which case I would propose to alter ardrig into rig. It is true that Leinster claimed to have given a large number of high-kings to Ireland ${ }^{2}$ ), whose number is variously put at ten, twenty-five, thirty-five, and even, counting from the time of the sons of $M i l$, at forty-six ${ }^{3}$ ); a figure which might easily be rounded off to fifty. But I think there are indications that our poem belongs to the Old-Irish period. Thus in the first line instead of ma dia seichi for iris ${ }^{4}$ ) I would propose to read ma dia seichither iris; though ma dia does not occur in the continental glosses.

In LL 316 the poem is said to have been addressed to Aed Find ( $A$ bräthair .i. fri Aed Find), which, as he was a brother of Aed Dub and thus shared with him the glory of royal descent; is not likely. Oengus, the son of Aed Find, seems to have succeded his uncle in the abbacy of Kildare (Aed Find mac Colmāin, mac dó Oengus abs) Cilli Dara, LL 316 a 23,

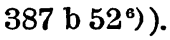

1) Cf. ni ba rí ar ān-Erinn mani tora coirm Cīalann, Anecd. I, p. 14, 2 and ib. p. 80 .

2) See on this 'Hail Brigit', p. 22.

3) Mad ó aimsir mac Mīled immorro, hit sé ríg .xl. for hËrind dīb:

Sé ríg da fichet co ngail gabsat hÉrind a Laignib, ó aimsir mac Míled 'mach cosin Rónán' rogíallach.

4) The construction of sechem with for instead of the accusative does not so far as I know occur elsewhere.

5) $a b$ - Fcs.

b) This later text wrongly has Aodh Finn mac Ronain.

Charlottenburg.

Kuno Meyer. 